\title{
Automated Extraction of Shoreline in Tuban Regency, East Java from Google Earth Imagery by Integrating Canny Edge Detector
}

\author{
Luhur Moekti Prayogo ${ }^{1}$, Sarono ${ }^{2}$ \\ ${ }^{1}$ Marine Science Study Program, Faculty of Fisheries and Marine, Universitas PGRI \\ Ronggolawe, Tuban, 62381, Indonesia \\ ${ }^{2}$ PT. Techno GIS Indonesia, Sleman, Yogyakarta, 55283, Indonesia \\ "E-mail: luhur.moekti.prayogo@unirow.ac.id
}

\begin{abstract}
The shoreline is an area that becomes the boundary between land and sea and experiences morphological changes over time. This region has a dynamic condition where various components (air, rocks, water) are interconnected. Multitemporal shoreline analysis is one of the critical parameters for monitoring coastal areas. This information can be used for morphodynamic modeling, coastal area management, and erosion and accretion studies. This study aims to analyze shoreline changes in the North Coast of Tuban Regency, East Java using the Canny Algorithm and Google Earth Imagery from 2000 to 2020. The Canny algorithm was chosen because it has been tested to produce sharp and good edges compared to other edge detection algorithms. From this research, it can be concluded that in the north coast of Tuban Regency, based on the sample years taken, the area's shoreline experienced the erosion of 0.297 - 1.566 meters/ five years. The edges generated using the Canny algorithm are practical in interpreting shorelines and making analysis faster. In the future, there is a need for more elaboration regarding the use of Google Earth imagery in shoreline analysis, especially in geometric corrections (Georeference). This elaboration is essential because it will affect the analysis results, especially the shoreline position.
\end{abstract}

\section{Keywords: Shoreline, Edge Detection Technique, Canny Algorithm, Google Earth, Tuban}

Abstrak. Garis pantai merupakan wilayah yang menjadi pembatas antara daratan dengan lautan serta mengalami perubahan morfologi dari waktu ke waktu. Wilayah ini memiliki kondisi yang sangat dinamis dimana berbagai komponen (udara, bebatuan, air) saling berhubungan. Analisis garis pantai multitemporal menjadi salah satu parameter penting untuk monitoring kawasan pantai. Informasi tersebut dapat digunakan untuk pemodelan morfodinamik, pengelolaan kawasan pesisir dan studi erosi dan akresi. Penelitian ini bertujuan untuk menganalisis perubahan garis pantai di Pesisir Utara Kabupaten Tuban, Jawa Timur menggunakan Algoritma Canny dan Citra Google Earth tahun 2000 hingga 2020. Algoritma Canny dipilih karena sudah teruji menghasilkan tepi yang tajam dan baik dibandingkan dengan algoritma deteksi tepi yang lain. Dari penelitian ini dapat disimpulkan bahwa di Pesisir Utara Kabupaten Tuban, berdasarkan sampel tahun yang diambil, garis pantai wilayah tersebut mengalami erosi sebesar 0,297 - 1,566 meter/ lima tahun. Tepi yang dihasilkan dengan algoritma Canny sangat membantu dalam proses interpretasi garis pantai dan membuat analisis menjadi lebih cepat. Kedepannya, perlu adanya elaborasi lebih mendalam mengenai penggunaan citra Google Earth dalam analisis garis pantai, khususnya pada koreksi geometriknya (Georeference). Hal ini penting untuk dilakukan karena akan mempengaruhi hasil analisis terutama posisi garis pantainya.

Kata kunci: Garis Pantai, Teknik Deteksi Tepi, Algoritma Canny, Google Earth, Tuban

\section{Introduction}

Tuban Regency is one of East Java districts from all 38 districts and cities in the province (Tuban Regency Government, 2018). Tuban Regency is located on the northern coast of Java Island with a shoreline of about $65 \mathrm{~km}$ with an area of $1,904.70 \mathrm{~km}^{2}$ (Tuban
Regency Government, 2018). In some of its areas, Tuban Regency is located in a coastal environment that makes these communities rely on the sea's produce by becoming fishermen. The coast becomes one of the areas of human activity that can be used for various fishing activities and 
settlements (Driptufany, 2020). The utilization will reduce land in the coastal area, and the land is carrying capacity, which causes erosion and sedimentation (Driptufany, 2020).

The shoreline becomes the barrier between the land and the ocean, which changes in morphology from time to time, which can be influenced by the sea level rise (Utami et al., 2017). This region has a very dynamic condition where air, rocks, and water are interconnected (Kasim, 2012). The coastal dynamics process is closely related to the coastal areas' management (Kasim, 2012). Alesheikh et al. (2007); Kasim (2012) argues that multitemporal shoreline analysis is one of the critical parameters for monitoring coastal areas. This information can be used for morphodynamic modeling, coastal area management, and erosion and accretion studies (Chand \& Acharya, 2010; Kasim, 2012).

Fuad et al. (2019); Suniada (2015) states that remote sensing techniques can analyze shoreline change. Along with the development of technology, one of the methods for shoreline extraction is to use edge detection techniques. Edge detection is the image processing stage to produce each object's edges in the image (Munir, 2019). The image's edge can be seen from the neighboring points' grey points ( $x$ and $y)$. The benefits of edge detection can also reduce the amount of data processed and can be used for change detection on the shoreline (Munir, 2019). In remote sensing, distinguishing the two objects is necessary because the image classification process will not be optimal if only using color characteristics.

Previous researchers have researched shorelines. Mulyadi et al. (2022) conducted a study of shoreline changes in the city of Dumai for three decades (30 years) using Landsat imagery and the Digital Shoreline
Analysis System (DSAS). This research shows that there is an average accretion and abrasion of 1.17 and 2.04 meters at the research location. Setyawan (2021) conducted research in Kuala Pesisir District, Nagan Raya Regency, Aceh using the Digital Shoreline Analysis System (DSAS) and Thresholding method in 2016-2020. This research shows changes in the shoreline by accretion and abrasion of 30.16 and $34.49 \mathrm{~m} /$ year.

Primasti et al. (2021) conducted a study to identify coastal vulnerability in Demak Regency using the Coastal Vulnerability Index (CVI) and the United States Geological Surveys (USGS) methods with five categories of coastal vulnerability. This research shows that the shoreline of the Demak Regency has a tendency to Erosion compared to Abrasion. Fuad (2021) conducted a study of shoreline changes on the coast of Situbondo Regency, East Java, using the one-line model method. The study results indicate that accretion and Abrasion occur in several research locations. Maulana et al. (2021) Conducted research on predicting shoreline changes in Bengkulu using the GENESIS (Generalized Model for Simulating Shoreline Change) method. The results showed that during the five years, the shoreline changes at the research site occurred $2.823 \mathrm{~m}$ of Abrasion and $1.677 \mathrm{~m}$ of sedimentation.

Adriat et al. (2021) Conducted shoreline research in Kijing Coastal Waters, Bengkayang Regency, West Kalimantan using the Single Transect (ST) and End Point Rate (EPR) methods on the DSAS tool. These studies indicate that at the study site, the dominant accretion occurred ranging from 0.5 to $21.34 \mathrm{~m}$. Atmojo et al. (2021) Conducting shoreline research using remote sensing techniques and data such as Landsat imagery with Unsupervised Classification, digitization, and overlapping methods. 
The research location shows that there is abrasion and accretion at the research location. Research on shorelines was carried out by Ramadhani et al. (2021) in the Coastal District of Saying, Demak Regency using remote sensing methods and the Digital Shoreline Analysis System (DSAS). The results showed a change in shoreline abrasion and accretion by $82 \%$ and $18 \%$, with a tendency to abrasion.

From the explanation above, a problem of how edge detection performs detecting shorelines in Google Earth imagery arises. Identifying the object's edge is vital because it is a preliminary study to observe changes in the shoreline more quickly. Therefore, this study aims to analyze changes in the shoreline in the North Coast of Tuban Regency, East Java using the Canny Algorithm. We have conducted a canny edge detector in Gili Raja Island, Sumenep (Prayogo \& Hidayah, 2021). This algorithm was chosen because it has been tested to produce sharp and good edges compared to other edge detection algorithms (Maini \& Aggarwal, 2009).

\section{Material And Method}

\section{Research Location}

This research is located at $6^{\circ}$ 53'27.51 "S and $112^{\circ} 3^{\prime} 38.10^{\prime \prime} \mathrm{E}$ in the North of Tuban Regency, East Java. After all, this location is suspected of experiencing abrasion yearly because it is located directly opposite the open sea. The shoreline observed in this study is approximately 650 meters long. Figure 1 shows the research location displayed on the Basemap World imagery.

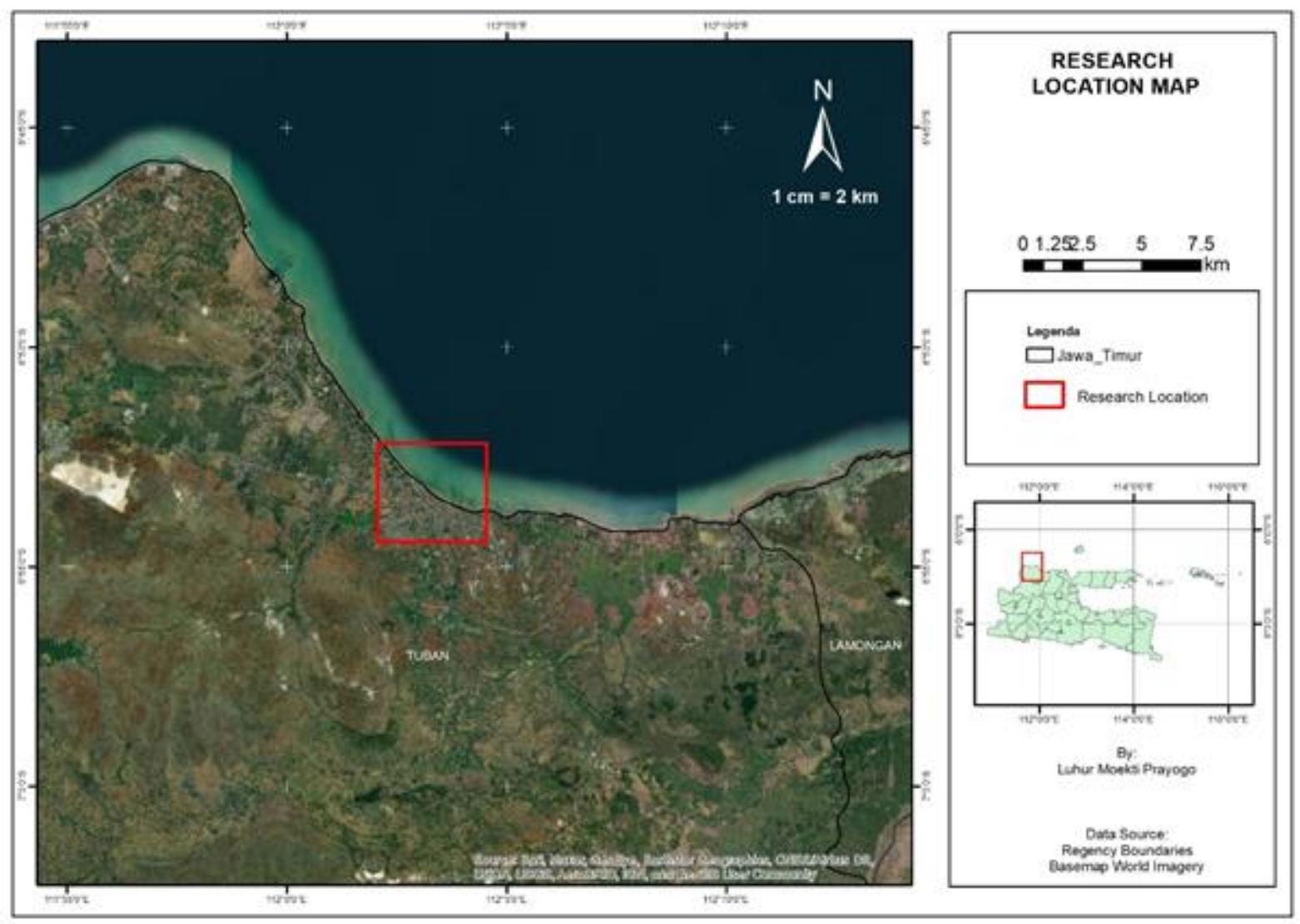

Figure 1. Research Location in Tuban Regency, East Java 


\section{Canny Algorithm}

Canny edge detection is a technique for extracting structural information that aims to reduce processed data. Based on Canny (1986); Deriche (1987) states that this process consists of at least five stages, namely: Applying a Gaussian filter so that the image becomes smoother and minimizes noise with the following equation (Gaussian filter $(2 \mathrm{k}+1) \times(2 \mathrm{k}$ $+1))$ ) (equation 1):

$$
H_{i j}=\frac{1}{2 \pi \sigma^{2}} \exp \left(-\frac{(i-(k+1))^{2}+(j-(k+1))^{2}}{2 \sigma^{2}}\right) ; 1 \leq i, j \leq(2 k+1)
$$

Then determine the image intensity gradient with the following equation (equation 2)

$$
G=\sqrt{G_{x}^{2}+G_{y}^{2} \ldots \ldots \ldots \ldots(2)}
$$

The edge direction angles represent vertical, horizontal, and two diagonals $\left(0^{\circ}, 45^{\circ}, 90^{\circ}\right.$, and $\left.135^{\circ}\right)$. Then it can apply steps such as (1) applying nonmaximum compressions to eliminate spurious responses to edge detection, (2) specifying a double threshold for determining potential image edges, and (3) Track edges with hysteresis: suppressing all other weak edges and not connected to the firm edge (Canny, 1986; Deriche, 1987).

\section{Result and Discussion}

Image Preprocessing

Before the image is filtered, the first thing to do is create a Ground Control Point (GCP) in Google Earth. GCP aims to adjust the coordinates on the map with coordinates in the field (Danoedoro, 2012). There are four GCPs used for georeferencing on five Google Earth maps. Tables 1 and 2 are information on the recording date of images and GCP used in this study.

Table 1. Google Earth imagery 2000-2020

\begin{tabular}{ccc}
\hline No & Recording Date & Cloud Cover Condition \\
\hline 1 & July 11, 2000 & Minimum \\
2 & July 28, 2003 & Minimum \\
3 & August 16, 2010 & Minimum \\
4 & July 8, 2016 & Minimum \\
5 & September 6, & Minimum \\
\hline
\end{tabular}

Table 2. GCP Information

\begin{tabular}{ccc}
\hline No & Latitude & Longitude \\
\hline 1 & $6^{\circ} 52^{\prime} 54.43^{\prime \prime S}$ & $112^{\circ} 3^{\prime} 22.49^{\prime \prime} \mathrm{E}$ \\
2 & $6^{\circ} 52^{\prime} 54.71 " \mathrm{~S}$ & $112^{\circ} 4^{\prime} 53.18^{\prime \prime} \mathrm{E}$ \\
3 & $6^{\circ} 53^{\prime} 55.11^{\prime \prime} \mathrm{S}$ & $112^{\circ} 3^{\prime} 27.80^{\prime \prime} \mathrm{E}$ \\
4 & $6^{\circ} 53^{\prime} 55.19^{\prime \prime S}$ & $112^{\circ} 4^{\prime} 48.98^{\prime \prime} \mathrm{E}$ \\
\hline
\end{tabular}

Image Processing 
Image edge processing using the Canny algorithm is carried out at least in several steps (Chapter 2). This step is carried out to obtain structural information for each observed object, namely the shoreline in Google Earth imagery, from 2000 to 2020. This detection has a strict definition compared to other edge detections, so that the results of Canny detection are better than other edge detection. Figure 2 shows the Google Earth multitemporal imagery data from 2000 to 2020 used in this study.

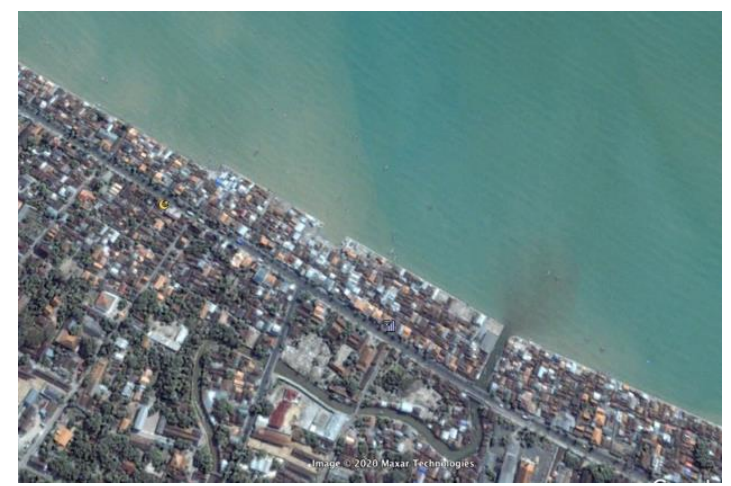

July 11, 2000

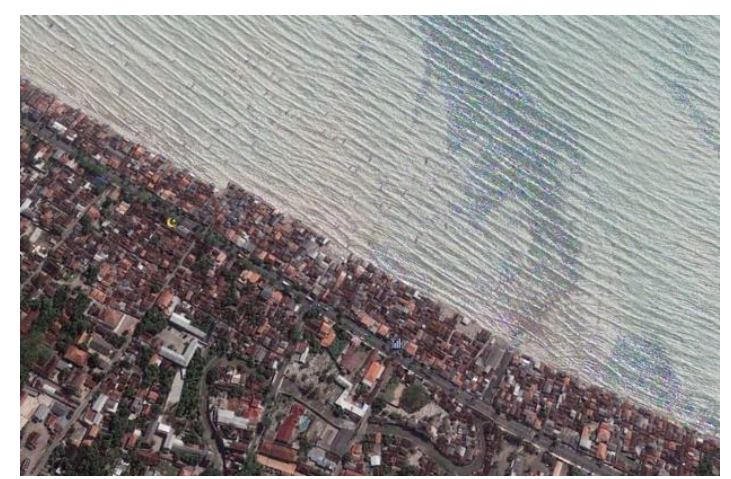

August 16, 2010

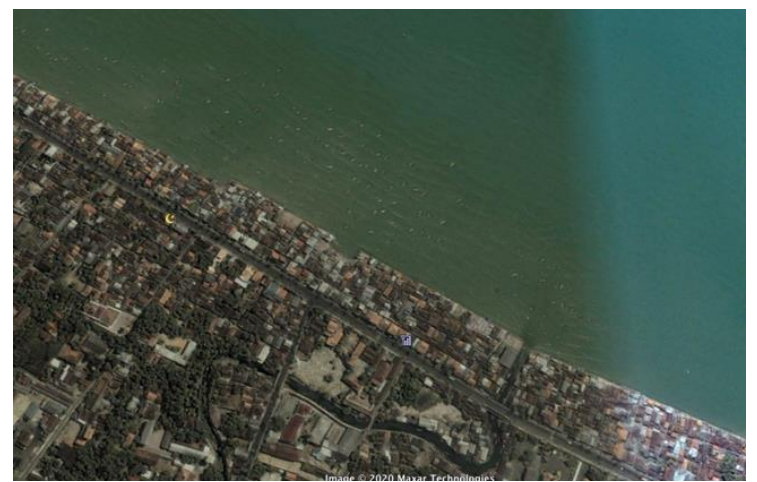

July 28, 2003

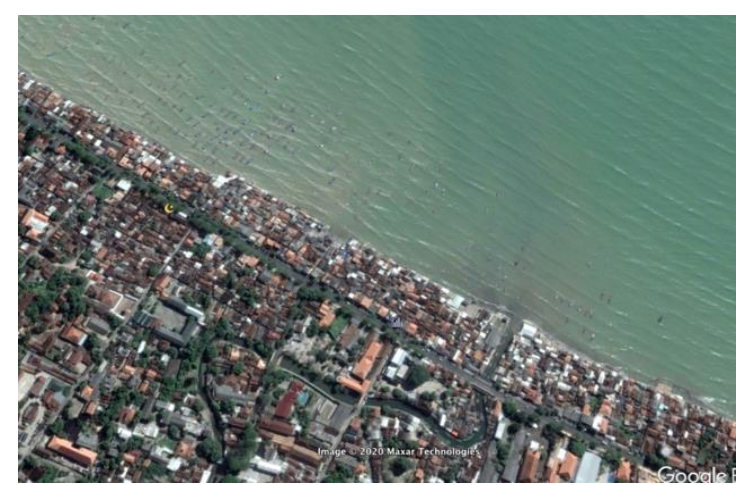

July 8, 2016

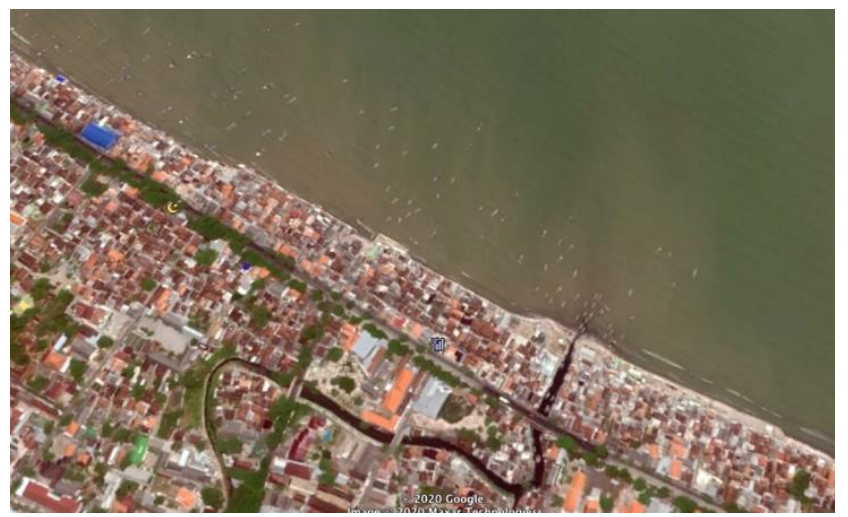

September 6, 2020

Figure 2. Google Earth Multitemporal Imagery from 2000 to 2020

The Canny algorithm has general criteria for detecting object edges. The operator's detected edge must be accurately localized in the center with marked once in each object. The detection must capture as many edges as possible to produce a suitable edge with minimal errors. According to 
requirements, the technique used in Canny detection to obtain edge information uses the calculus of variations function. The first derivative of Gaussian can explain this function. Figure 3 shows the results of Canny edge detection for shoreline analysis in the Tuban Regency, East Java.

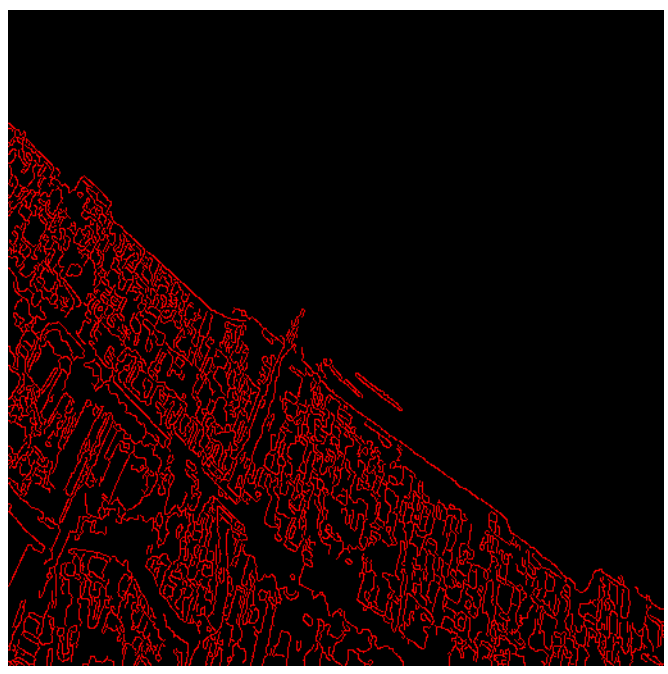

2000

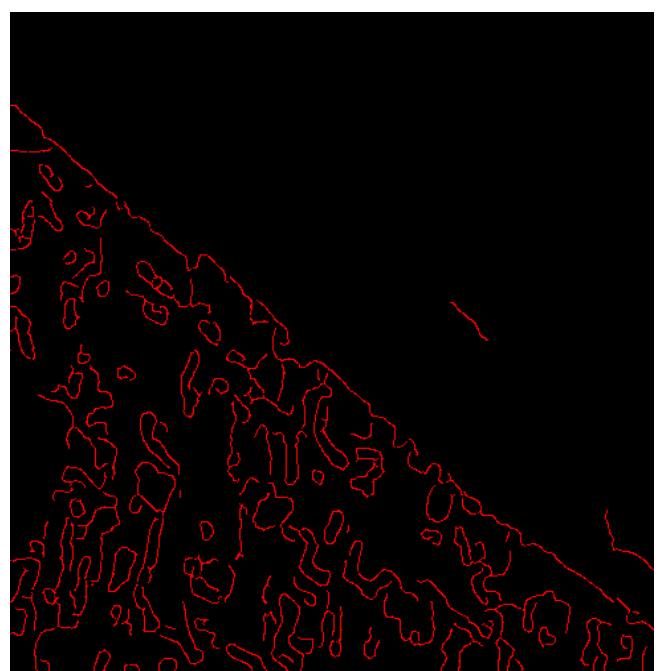

2010

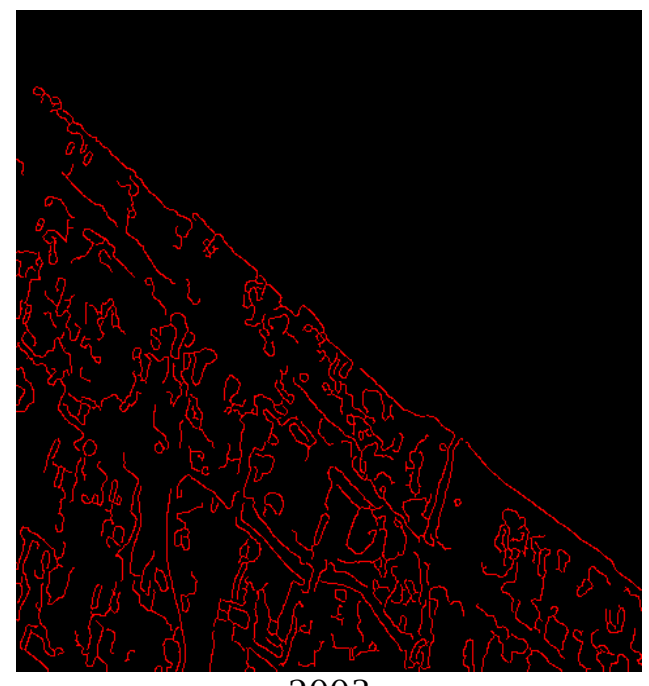

2003

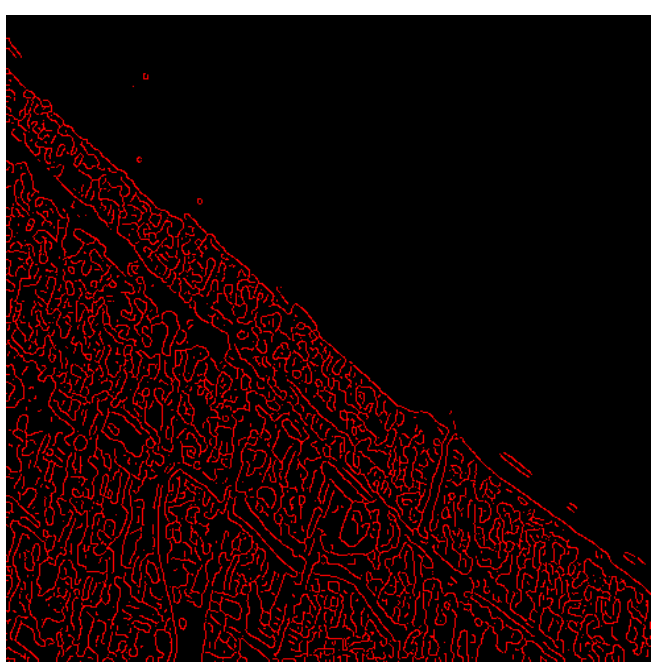

2016 


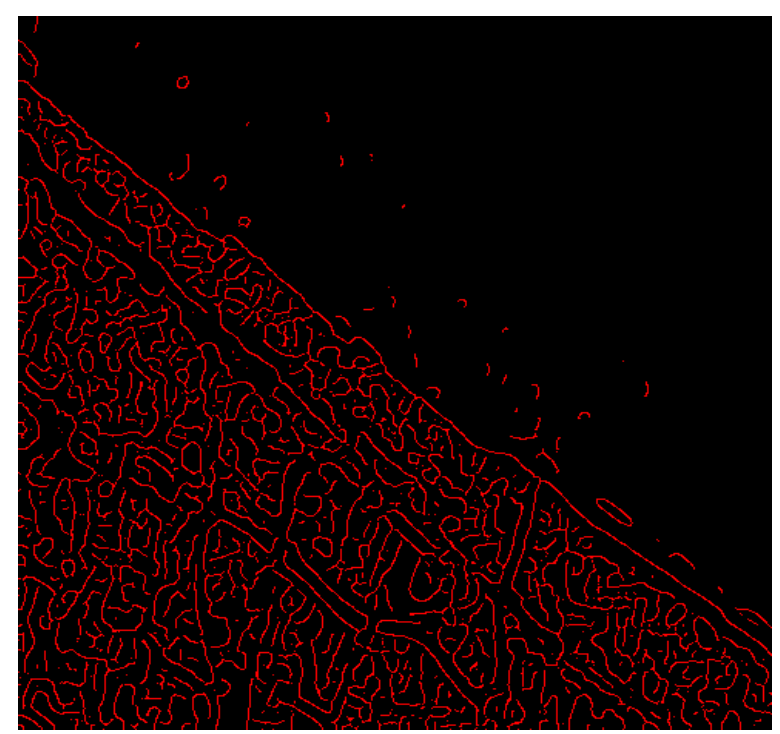

2020

Figure 3. Canny Algorithm Results from 2000 to 2020 in the Tuban Regency, East Java

The Gaussian filter on the image minimizes noise so that the object's edges are easily detected. The image's noise significantly affects the shoreline's extraction, so smoothing is needed at this stage. Besides, this filter uses a kernel window that is not static and can be changed according to each object's needs being filtered.

The next step is to thin the edges of the image. This process is carried out to determine the change's location in the highest / sharpest intensity value to produce a more authentic and accurate image edge. The final process of shoreline detection with Canny is edge tracking with hysteresis. This stage aims to trace the edges of the weak pixels caused by the unconnected image's noise response. From the detection process, the following is the appearance of the shoreline in 2000, 2003, 2010, 2016, and 2020 in the North Coast of Tuban Regency, East Java (Figures 4). 


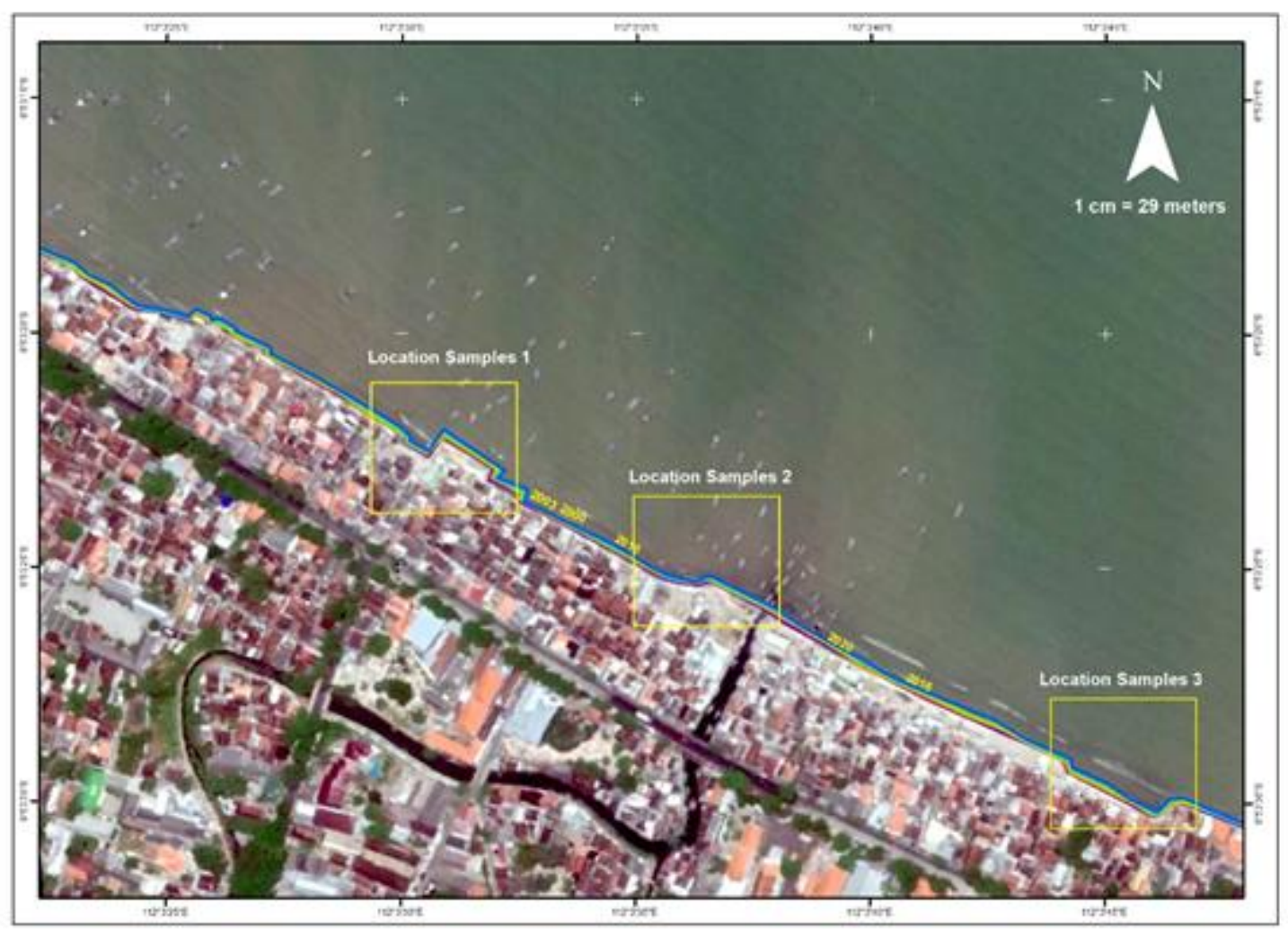

Figure 4. Shoreline 2000, 2003, 2010, 2016 and 2020

From the picture, we can see that the shoreline has shifted every year in the image sample due to erosion. In the first location, in 20002003 , there was a shift of $1,148 \mathrm{~m}$, in 2003-2010 it shifted of $1,439 \mathrm{~m}$, in 2010-2016 it shifted of $1,022 \mathrm{~m}$, and 2016-2020 experienced a shift of $0.796 \mathrm{~m}$. Then in the second location, in 2000-2003, there was a shift of $0.861 \mathrm{~m}$, in 2003-2010 it shifted of
$1.051 \mathrm{~m}$, in 2010-2016 it shifted of $0.667 \mathrm{~m}$, and 2016-2020 experienced a shift of $0.313 \mathrm{~m}$. Finally, in the third location, in 2000-2003, there was a shift of $0.974 \mathrm{~m}$, in 2003-2010 it shifted by $1.566 \mathrm{~m}$, in 2010-2016 it shifted $0.297 \mathrm{~m}$, and 2016-2020 experienced a shift of $1.157 \mathrm{~m}$. Table 3 shows the shoreline shift information for each sample of the study locations.

Table 3. Shoreline change for each location

\begin{tabular}{cccc}
\hline Time & $\begin{array}{c}\text { Shift Locations 1 } \\
\text { (meters) }\end{array}$ & $\begin{array}{c}\text { Shift Locations 2 } \\
\text { (meters) }\end{array}$ & $\begin{array}{c}\text { Shift Locations 3 } \\
\text { (meters) }\end{array}$ \\
\hline $2000-2003$ & 1,148 & 0,861 & 0,974 \\
$2003-2010$ & 1,439 & 1,051 & 1,566 \\
$2010-2016$ & 1,022 & 0,667 & 0,297 \\
$2016-2020$ & 0,796 & 0,313 & 1,157 \\
\hline
\end{tabular}

\section{Conclusion}

From this research, it can be concluded that in Pesisir Utara, Tuban Regency, based on the sample years taken, the area's shoreline experienced the erosion of 0.297 - 1.566 meters / five years. The edges generated using the Canny algorithm are very helpful in interpreting shorelines and making analysis faster. In the future, there is a need for more elaboration regarding the use of Google Earth imagery in 
shoreline analysis, especially in geometric corrections. This elaboration is essential because it will affect the analysis results, especially the shoreline position.

\section{Reference}

Adriat, R., Risko, R., Apriansyah, A., Muhardi, M., Susiati, H., Zibar, Z., \& Fitriani, F. (2021). Analisis Perubahan Garis Pantai di Wilayah Perairan Pantai Kijing Kabupaten Bengkayang Kalimantan Barat. Jurnal Perikanan Dan Kelautan, 11(1), 101-113.

Alesheikh, A. A., Ghorbanali, A., \& Nouri, N. (2007). Coastline change detection using remote sensing. International Journal of Environmental Science \& Technology, 4(1), 61-66.

Atmojo, A. T., Welly, T. K., Simbolon, K., \& Zulfikar, A. N. (2021). Studi Perubahan Garis Pantai Pesisir Kota Bandar Lampung Menggunakan Data Penginderaan Jauh. Journal of Science, Technology, and Visual Culture, 1(3), 149-154.

Canny, J. (1986). A Computational Approach to Edge Detection. IEEE Transactions on Pattern Analysis and Machine Intelligence, 8(6), 679-698. https://doi.org/10.1109/TPAMI.1 986.4767851

Chand, P., \& Acharya, P. (2010). Shoreline change and sea level rise along coast of Bhitarkanika wildlife sanctuary, Orissa: An analytical approach of remote sensing and statistical techniques. International Journal of Geomatics and Geosciences, 1(3), 436.

Danoedoro, P. (2012). Pengantar Pengindraan Jauh Digital. In Benedicta Rini W (Ed.), Penerbit ANDI (1st ed.). Penerbit ANDI. 397 hlm.

Deriche, R. (1987). Using Canny's criteria to derive a recursively implemented optimal edge detector. International Journal of Computer Vision, 1, 167-187. https://doi.org/10.1007/BF00123 164

Driptufany, D. M. (2020). Deteksi Perubahan Garis Pantai Kabupaten Padang Pariaman dan Kota Pariaman Menggunakan Aplikasi Penginderaan Jauh. JURNAL TEKNIK SIPIL ITP, 7(2), 43-50.

Fuad, M. A. Z. (2021). Pemodelan dan Analisis Perubahan Garis Pantai di Kabupaten Situbondo, Jawa Timur. JFMR (Journal of Fisheries and Marine Research), 5(2), 335349.

Fuad, M. A. Z., Yunita, N., Kasitowati, R. D., Hidayati, N., \& Sartimbul, A. (2019). Pemantauan Perubahan Garis Pantai Jangka Panjang Dengan Teknologi Geospasial Di Pesisir Bagian Barat Kabupaten Tuban, Jawa Timur. Jurnal Geografi, 11(1), 48-61. https://doi.org/2549-7057

Kasim, F. (2012). Pendekatan beberapa metode dalam monitoring perubahan garis pantai menggunakan dataset penginderaan jauh Landsat dan SIG. Jurnal Ilmiah Agropolitan, 5(1), 620-635.

Maini, R., \& Aggarwal, H. (2009). Study and comparison of various image edge detection techniques. International Journal of Image Processing, 3(1), 1-12. https://doi.org/http://www.doaj. org/doaj?func $=$ openurl\&genre $=$ art icle $\&$ issn $=19852304 \&$ date $=2009 \&$ volume $=3 \&$ issue $=1 \&$ spage $=1$

Maulana, F. A., Amri, K., \& Besperi, B. (2021). Prediksi Perubahan Garis Pantai Bengkulu (Studi Kasus Pantai Zakat Kota Bengkulu). RADIAL: Jurnal Peradaban Sains, Rekayasa Dan Teknologi, 9(1), 1522.

Mulyadi, A., Hamidy, R., Musrifin, E., Efriyeldi, E., \& Jhonnerie, R. (2022). Tiga dekade laju 
perubahan garis pantai di Kota Dumai. Dinamika Lingkungan Indonesia, 9(1), 25-31.

Munir, R. (2019). Segmentasi Citra. Program Studi Teknik Informatika Sekolah Teknik Elektronika. Institut Teknologi Bandung.

Prayogo, L. M., \& Hidayah, Z. (2021). Utilization of Multitemporal Landsat Data for Coastline Change Analysis Using Canny Edge Detector. Jurnal Kelautan: Indonesian Journal of Marine Science and Technology, 14(2), 9199.

Primasti, T. P. G., Hariyadi, H., Rochaddi, B., \& Widada, S. (2021). Pemantauan Kerentanan Fisik di Pesisir Kabupaten Demak (Studi Kasus Perubahan Garis Pantai). Indonesian Journal of Oceanography, 3(1), 44-54.

Ramadhani, Y. P., Praktikto, I., \& Suryono, C. A. (2021). Perubahan Garis Pantai Menggunakan Citra Satelit Landsat di Pesisir Kecamatan Sayung, Kabupaten
Demak. Journal of Marine Research, 10(2), 299-305.

Setyawan, F. O. (2021). Analisis Perubahan Garis Pantai Menggunakan Digital Shoreline Analysis System Di Kecamatan Kuala Pesisir, Kabupaten Nagan Raya, Aceh. JFMR (Journal of Fisheries and Marine Research), 5(2), 368-377.

Suniada, K. I. (2015). Deteksi perubahan garis pantai di Kabupaten Jembrana bali dengan menggunakan teknologi penginderaan jauh. Jurnal Kelautan Nasional, 10(1), 13-19.

Tuban Regency Government. (2018). Tuban Profile. https://tubankab.go.id/page/profi l-tuban

Utami, W. S., Subardjo, P., \& Helmi, M. (2017). Studi Perubahan Garis Pantai Akibat Kenaikan Muka Air Laut Di Kecamatan Sayung, Kabupaten Demak. Journal of Oceanography, 6(1), 281-287. 